\title{
Teaching for Active Learning in Two Primary-Level Islamic Schools (Madrasahs) in North Sumatra
}

\author{
Suprayetno W., Irwan Nasution,,${ }^{\mathrm{a},}$ Amiruddin Siahaan, ${ }^{\mathrm{a}}$ Farida Jaya, ${ }^{\mathrm{a}}$ Tien Rafida, ${ }^{\mathrm{a}}$ \\ Fibri Rakhmawati, ${ }^{\mathrm{a}}$ and Suharni ${ }^{\mathrm{a}}$ \\ ${ }^{a}$ State Islamic Studies Institute-North Sumatra, Indonesia
}

\begin{abstract}
Teaching for active learning is an instructional strategy that has been promoted for some time in Indonesia through various government educational reform initiatives and international development efforts. These efforts, however, have tended to target teachers in public primary schools (SD: sekolah dasar) or public junior high schools (SMP: sekolah menengah pertama) rather than equivalent schools in the Islamic education sector (madrasah ibtidâ 'iyah and madrasah tsanawiyah). Utilizing data gathered from focus group discussions, individual interviews, and classroom discussions, this action research study examined the specific challenges faced by Islamic Studies teachers in teaching for active learning in two public Islamic primary schools (MIN: madrasah ibtidâ 'iyah negeri) in the district of Deli Serdang, North Sumatra. Our article goes on to describe the difficulties Islamic Studies teachers have in applying active learning teaching strategies learned in demonstrations of teaching for active learning in science, mathematics and other secular subjects to Islamic Studies.
\end{abstract}

\begin{abstract}
Abstrak
Active learning merupakan strategi pembelajaran yang gencar dipromosikan di Indonesia melalui berbagai inisiatif perbaikan pendidikan dan pengembangan oleh lembaga internasional. Namun, upaya-upaya ini cenderung lebih ditujukan untuk guru-guru di Sekolah Dasar (SD) atau Sekolah Menengah Pertama (SMP), daripada untuk sekolah keagamaan seperti Madrasah Ibtida'iyah (MI) dan Madrasah Tsanawiyah (MTS). Berdasarkan data dari diskusi kelompok, wawancara individu dan diskusi di kelas, penelitian tindakan kelas ini menganalisa berbagai kendala spesifik yang dihadapi para guru Agama Islam dalam menerapkan active learning di dua MI Negeri di Deli Serdang, Sumatera Utara. Artikel ini memaparkan kesulitan yang dialami guru Agama Islam dalam mengaplikasikan strategi active learning yang mereka pelajari melalui pelatihan active learning untuk sains, matematika dan mata pelajaran umum lainnya.
\end{abstract}

Key Words: Islamic Education, Active Learning, Religious Studies, Indonesia

\section{Introduction}

In Indonesia, basic education is compulsory for all citizens between the ages of seven and fifteen and includes both public primary schools and public junior high schools (SD: sekolah dasar and SMP: sekolah menengah pertama) as well as Islamic primary and junior high schools (madrasah ibtidâ'iyah and madrasah tsanawiyah, respectively). While this basic structure has been in

*Corresponding author. Address: IAIN North Sumatra, Medan, Indonesia. Email: irwan_arafah@yahoo.com.sg. place for decades, curricula, and the teaching strategies designed to implement them, have changed many times since Indonesian independence. Currently, at the primary level-Grades 1,2 and 3 - the curriculum is supposed to be organized thematically rather than by subject matter, as it is in the higher grades. Teachers are expected to plan thematic units that coordinate instruction in a variety of subjects - math, science, social studies, et ceteraaround a topic relevant to students' needs, interests and experiences and consistent with their level of psycho-social development. Indonesian curriculum planners have determined that children at this level are at a developmental stage at which the 
learning process is still quite dependent on direct experiences with concrete objects in their daily lives. Thus thematic learning at this level stresses learning activities rooted in the daily lives of students and designed to develop social skills such as cooperation, tolerance, communication and responsiveness to the ideas of others as well as academic knowledge.

Policy too has shifted from a long standing emphasis on improving access to education for all children to a more recent emphasis on improvements in educational quality (Bjork 2003). One of the means used to improve educational quality has been the development of teachers' qualifications and training regarding subject matter, learning processes and assessment of results as well as their ability to solve educational and teaching challenges through action research. Such efforts, it is believed, will enhance the professionalization of the teaching force in Indonesia.

One pedagogical strategy that has long been considered integral to the Ministry of National Education's efforts to reform curricula and improve teaching in Indonesian primary schools is active learning (Government of Indonesia 1989). Conceived as a learning process in which students are actively involved in and learn to care for their own learning, teaching for active learning encourages teachers to use techniques that require students to think and analyze, create their own opinions, and practice and apply their own learning rather than passively absorbing what the teacher provides. Introduced in the 1984 revision of the 1975 national curriculum, active learning was socialized throughout the Indonesian educational system. The results, however, were not satisfying. Teachers encountered problems in applying active learning strategies due in part to the lack of training provided by the Indonesian government. Despite these challenges, education officials continued to stress the importance of teaching for active learning, emphasizing it again in a subsequent curriculum revision introduced in 1994. Since then efforts to promote active learning have generally paralleled national educational reform efforts. These initiatives have encouraged teachers to minimize the use of lectures, individualize learning tasks based on the learners' needs and interests, and actively involve the students in the learning process.

Encouragement of teaching for active learning continued into the new millennium under the auspices of the USAID-funded project, Decentralized Basic Education 2 (DBE2). Implemented from 2006-2011 by the US-based Education Development Center, DBE2 was a five-year effort to improve the quality of teaching and learning in the primary schools of six Indonesian provinces, including North Sumatra. The project developed training materials in science, mathematics, Bahasa Indonesia, and planning and evaluation, and conducted workshops for teachers, principals, supervisors and school committees in 174 schools serving approximately 40,000 students in North Sumatra. Follow up mentoring and support was also provided by master teacher trainers who visited with teachers in their schools. Teaching strategies using active learning methods were an explicit component of all training packages. Teachers not involved in DBE2 programs have also received active learning training at the city, regency, and province levels from the Educational and Teaching Service (Dinas Pendidikan dan Pengajaran), the Educational Quality Assurance Institute (Lembaga Penjaminan Mutu Pendidikan), or the Education and Training Center of the Ministry of Religious Affairs. Thus, the efforts of the DBE2 project endeavored to complement and support initiatives of the Ministry of National Education and the Ministry of Religious Affairs to improve the quality of basic education in North Sumatra by encouraging the wider use of active learning methods.

As a result of both efforts, teachers in the province have attempted to implement teaching for active learning inasmuch as the basic principles of active learning are put into practice: That is the teacher is not the only one active in the classroom instructional process, and there are activities which involve the students in the learning process based on the teachers' plans. However, anecdotal evidence from classroom observations and conversations with teachers in some public Islamic primary schools (MIN: madrasah ibtida'iyah negeri) by staff from the State Islamic Studies Institute-North Sumatra (IAIN-SU: Institut Agama Islam NegeriSumatera Utara) involved in DBE2 suggested that challenges remained in ensuring that teaching for active learning was widely practiced in the elementary madrasahs of North Sumatra. While some teachers of the subject matter used to demonstrate teaching for active learning strategies in DBE2 training were using techniques modeled in their training, MIN teachers of other subjects seemed to have difficulty transferring what they learned to their own classrooms. Other MIN teachers' understanding of teaching for active learning seemed to be limited to the idea that it is something different from lecturing; therefore, if they were not lecturing, they were teaching for active learning.

In order to better understand these and other challenges teachers face in teaching for active learning in MINs in North Sumatra and, where necessary, facilitate their efforts to overcome those challenges, a team of lecturers from IAIN-SU designed and implemented an action research project intended to answer the following questions: (1) What is the nature of the challenges to teaching for active learning in madrasahs? (2) What is needed to assist teachers and other educational staff in madrasahs to overcome these impediments to active learning? 


\section{Research Sites and Setting}

To address these questions the research team selected two private Islamic primary schools that had received DBE2 training in the district of Deli Serdang, North Sumatra. The district of Deli Serdang surrounds the provincial capital of Medan, which is located on the north-east coast of the island of Sumatra, a region known for its cultural and religious diversity. Both schools are relatively new, established in 2003 and 1995 respectively, and both aim to inculcate Islamic values consistent with the guidance of the Qur'an and the Sunnah (teachings of the Prophet Muhammad) while providing the solid education in the arts, sciences, social sciences, and technology necessary to become self-supporting, contributing members of Indonesian society. The schools serve a student population comprised of the children of poor laborers, shopkeepers, farmers and other lower socioeconomic status occupations.

\section{Research Design and Methods}

Our inquiry into the factors that impede or facilitate teaching for active learning in two primary Islamic schools was designed as an action research project with the ultimate goal of both improving classroom instruction in the targeted schools and improving teacher trainers' understanding of the conditions that impede teaching for active learning in primary-level madrasahs (Stringer 2007).

The first cycle of data gathering was guided by tentative questions that emerged from the team's analysis of data gathered in the course of School Professional Assistance (Bimbingan Profesional Sekolah) provided by DBE2 trainers to the two schools. The team conducted initial visits to both schools to explain the nature and purpose of the research and to secure permission from teachers and relevant school leaders to carry it out. Initially, both headmasters and teachers were uncomfortable with the proposed research because they were concerned that it would be used in the formal monitoring and evaluation process. However, once the team clarified the aims of the research and its intention to assist the schools in their efforts to improve classroom instruction, both schools welcomed the research team.

The action research team included lecturers from IAIN-SU, including lecturers from the Faculty of Teacher Training, as well as two DBE2 master teacher trainers (MTTs) who had assisted the schools in the past. The presence of the DBE2 MTTs helped the team clarify the research project's connection to the schools' previous participation in DBE2 training and allay concerns that the research might be connected to the monitoring and evaluation regime of the local Department of Education. The MTTs existing relationships with teachers in both schools and their participation in the DBE2 training helped to facilitate access to the research sites and to ensure the team's familiarity with the organization and purpose of that training vis a vis teaching for active learning.

Once access to both schools was granted the team began gathering initial data by conducting focus group discussions, individual interviews, and classroom observations. Because teaching is a complex activity with a variety of critical components, including lesson planning, selection of appropriate materials, determining instructional objectives, use of appropriate media and the selection of assessment procedures, all with the needs of specific learners in mind, classroom observations were focused on a number of activities, including class preparation, classroom organization and management, use of instructional media, assessment strategies, and teaching strategies. Two focus group discussions were conducted with headmasters, teachers and members of school committees designed to ascertain their perspectives, ideas, attitudes and behaviors toward active learning. More than a dozen interviews with individual teachers and six classroom observations were then conducted in order to determine the extent of implementation of active learning methods as well as the motivations and challenges encountered by teachers in their efforts to teach for active learning. All interviews and focus group discussions were recorded, transcribed and analyzed for emergent themes that might shed light on the nature of the difficulties and successes teachers of both schools were having in teaching for active learning. Classroom observations were recorded using a digital video recorder and similarly analyzed. Analysis of the results of this initial cycle of data gathering led the team to focus its second round of data collection on the use of active learning teaching strategies in Islamic studies and related courses. The same methods of data collection and analysis conducted in the first stage of the research project were repeated in this stage.

\section{Teaching for Active Learning in Two MINs in Deli Serdang}

Generally, teachers prepare for classes and complete administrative tasks outside of school hours on weekends and holidays. However, in these two schools poor salaries force most teachers to pursue other income producing activities beyond their teaching jobs, such as farming, retail and other low-wage occupations, or teaching in other schools, a common predicament for teachers throughout Indonesia (Nilan 2003). As a result teachers are not able to prepare syllabi and lesson plans for all of the multiple subjects and classes they teach. While they are able to comply with some of their administrative requirements-grade reports, for instance - they simply do not have time to complete all of the administrative tasks expected of them. 
Classes usually started with students lining up to enter the classroom. As they entered, the teacher asked questions which students were required to answer as they entered. Students were normally seated in pairs or small groups, and classrooms were decorated with student-produced displays and portfolios. Teachers tended to direct oral questions to individual students. Student learning was assessed via written tests at the end of instructional units. Other forms of assessment relevant to active learning were not observed.

Due to severely limited budgets, instructional media available for teachers' use was quite limited. A few commercially produced media kits were available, but some teachers were not familiar with them and they were kept securely locked in the headmaster's room when not in use. Most of the instructional media used was produced by teachers themselves from inexpensive, easy-to-find materials. These included small cards, dolls, paper flowers, painting materials, et cetera as well as geometric figures like cubes, blocks, triangles, pyramids, et cetera for use in mathematics instruction. At least one science teacher used elements of the school environment, such as trees planted in the schoolyard, as instructional aids in biology. While teachers did the best they could to enliven classroom instruction with appropriate instructional media, shortages of creative skills, time, and money-their own and the school's - severely hampered their efforts.

In terms of classroom management, teachers appeared to have few difficulties with traditionally organized classrooms where teachers lecture and students, seated in neat rows, listen. However, when teachers attempted to utilize active learning methods, they tended to have problems managing time as well as difficulty in balancing the needs of very active students and very passive students. In one of the Islamic school's classrooms, partitions consisted of a half wall that allowed noise from other classrooms to spill over and disturb the classes under observation. This baselevel noise, combined with the increased noise and movement that resulted when teachers tried active learning methods, contributed to the reluctance of many teachers to teach for active learning.

At the primary level, from Grades 1 to 3 the curriculum is organized thematically, which would seem to be particularly conducive to active learning methods. However, interview and observational data suggest that the teachers of both madrasahs have a hard time understanding how to plan and deliver thematic lessons. They have not been taught this way themselves. Moreover, their textbooks and other instructional materials are organized by subject matter. One teacher complained,

I am a third grade teacher, and in this grade the learning is supposed to be thematic. I do not understand how to apply it. In addition, the books provided here are based on subjects, but I am required to provide a syllabus and teaching plan organized around thematic units. I do not know how to unite all the subjects in one theme. For me, social science is social science, civics is civics, and so on. I really do not understand. (Focus Group Discussion Participant, 21 May 21 2008)

Another teacher admitted, "I cannot fulfill the requirements for thematic learning" (Focus Group Discussion Participant, 21 May 2008). Thus the lack of training and professional experience with thematically organized curricula, the lack of instructional materials like textbooks, workbooks, et cetera that are organized thematically, and the lack of time to carefully prepare for classes conspire to undermine any potential that a conducive organization of curriculum might have in facilitating the use of active learning methods.

Teachers' perceptions of active learning further complicated their ability to teach for active learning because they tended to stress what teachers do not have and what they believe they cannot do. For instance, one teacher stated, "Here in this school we have decided to apply active learning, which requires media, class administration, and its own system of assessment" (Teacher Interview, 28 May 2008). Another teacher describes active learning as "the teaching that is applied in the class in which the media is used and students are arranged in groups and they learn by singing and sharing ideas" (Teacher Interview, 9 June 2008). Teachers tend to believe that teaching for active learning requires the extensive use of classroom media. If little media is available, as is the case in both schools, teaching for active learning is, in their minds, not possible. "In the learning process we have to provide media, so as a teacher we have to create cheap and easy media. My problem is that I can't allocate the money for this! Yes, it is about budget. If we . . I myself want to create media, but other teachers do not want to do that. So that is a problem" (Teacher Interview, 15 October 2009). Moreover, many teachers assume that if instructional media are used in class then active learning is taking place. Thus in teachers' minds active learning is thought to require material resources that many simply do not have.

This emphasis on the importance of media as something purchased or locally constructed makes teaching for active learning in Islamic studies particularly difficult. These problems stemmed partly from the nature of the DBE2 training itself, which focused on mathematics, science and Bahasa Indonesia. This training gave teachers some familiarity with active learning methods in these specific subject areas; however, Islamic studies teachers reported difficulties in generalizing these strategies to Islamic studies, an important component of the curriculum of both 
schools. Most had difficulty imagining how certain abstract theological or spiritual concepts could be conveyed materially. This difficulty was further complicated by the fact that some forms of representation are religiously proscribed in Islam as idolatrous.

Interview data also suggest that teachers are unclear about the purpose and nature of student activity in active learning. They recognize its value in preventing boredom and encouraging participation, but connection to learning seems less clear. One teacher, for instance, described active learning as "a strategy in teaching to make the students active so they do not get bored in learning" (Teacher Interview, 16 October 2009). Another teacher reported, "Sometimes we apply learning by fun, group discussion, or students find the story themselves and have to learn what they should learn from the story" (Teacher Interview, 17 October 2009). The entertainment value of student activity is clear, but its contribution to learning academic content is less so. Thus there is a danger that active learning will be perceived as just games rather than an effective instructional strategy.

Teachers also expressed their confusion over the methods of assessment appropriate for active learning. As discussed above, teachers' assessment practices remain focused on traditional activities such as written tests, homework assignments, and oral questioning of students. Moreover, some teachers continue to see the purpose of evaluation as sorting students according to ability rather than measuring learning: "If we apply, for example, role playing, how should we determine one student has a better grade than the other? It means that this needs a special technique of assessment which we do not know how to do" (Teacher Interview, 17 October 2009).

\section{Problem Identification and Intervention}

Our analysis of the data gathered across multiple cycles of data collection revealed five problematic areas in teaching for active learning among primary-level madrasah teachers in these two schools.

1. Teachers have problems in teaching for active learning, especially for spiritual and abstract concepts.

2. Therefore, teachers cannot develop media for such concepts in Islamic Studies.

3. They have difficulty identifying other appropriate teaching strategies for Islamic Studies.

4. They have difficulties describing the process of teaching step by step in their teaching plan for Islamic Studies

5. Teachers of Grades 1-3 have difficulty in preparing thematic lessons in Islamic Studies.
The identification of these specific problems led the action research team from IAIN-SU to design and implement further training in teaching for active learning specifically targeted to Islamic Studies. The team worked with the teachers and headmasters to provide training, assistance, and problem solving related to teaching for active learning in terms of administration, media, evaluation, and class management. The training involved a series of six half-day sessions over a three-month period addressing issues of administration, class management, use of media, and evaluation in active learning for Islamic studies. As part of the training, teachers were given opportunities to conduct peer-teaching lessons utilizing active learning. Teachers then applied what they had learned about teaching for active learning in their own classrooms with members of the research team serving as sympathetic observers. The intervention concluded with teachers attempting to implement teaching for active learning methods in their own classroom without research team support.

\section{Conclusions and Recommendations}

Islamic Studies teachers in both schools voluntarily participated in training interventions carried out by members of the research team. These interventions involved teachers in discussions of cooperative learning strategies, teaching simulations using cooperative learning strategies, and finally employing cooperative learning in their own classroom. They also participated in training sessions aimed at enhancing their understanding of thematic instruction. Interview and observational data were gathered on all phases of the intervention and analyzed for emergent themes relevant to the challenges teachers faced in teaching for active learning in Islamic studies.

This data from these two primary-level Islamic schools suggest that Islamic Studies teachers are now more aware of active learning as an instructional strategy. Follow up visits by the research team two months after these training interventions suggested that teachers understanding of thematic units and their ability to use cooperative learning strategies were better. Some teachers were also trying to teach for active learning. One teacher reported, "I bring the students to the market to practice shopping skills, such as how to pay the cashier and taking notes on expenses" (Teacher Interview, 9 June 2008). But the preponderance of the data collected in this study demonstrates that most teachers still do not completely understand or utilize active learning methods. They recognize its outward signs-student activity, use of instructional media, fun - but they do not yet fully understand the principles of learning embedded in active learning nor are they convinced that what looks good in training is applicable in the material conditions of their schools. Thus they 
have not yet given up traditional instruction for active learning methods.

However, our research also suggests that once teachers are helped to overcome their belief that active learning requires resources, material conditions, and skills that they do not have, teachers and students together are able to adapt and become familiar with this and other educational innovations. Creativity belongs to everyone. It does not know social and economic class, but sometimes it needs a motivational spark to bring it into reality. Our research indicates that teachers, with all their weaknesses, can show their creativity in teaching and are able to teach for active learning. This is also true of Islamic studies teachers in the MIN. Religiously appropriate active learning methods are possible in Islamic studies, and Islamic studies teachers are open to new teaching strategies. But more attention needs to be paid to the specific needs and contexts of Islamic studies teachers in future training. Specific programs are needed for madrasahs which involve Islamic education experts in the training of teachers in active learning methods. This is important in order to make it possible for teachers, students, and madrasah graduates to engage in the on-going struggle to learn and thus to contribute to the betterment of themselves and their communities within the context of Islamic values.

\section{References}

Bjork, Christopher. 2003. "Local Responses to Decentralization Policy in Indonesia." Comparative Education Review 47 (2): 184-216.

Government of Indonesia. 1989. Concerning National Education System, Law No.2 [Undang-undang Nomor 2 Tahun 1989 Tentang Sistem Pendidikan Nasional]. Jakarta: Government of Indonesia.

Nilan, Pam. 2003. "Teacher Work and Schooling in Bali." International Review of Education 49 (6): 563-584.

Stringer, Ernest. 2007. Action Research. 3rd ed. Thousand Oak, CA: SAGE Publications. 